\title{
Synthesis and SOD Activity of Manganese Complexes of Pentaaza Macrocycles Containing Amino- and Guanidino-auxiliary
}

\author{
Wonchoul Park and Dongyeol Lim* \\ Department of Chemistry, Sejong University, Seoul 143-747, Korea.*E-mail: dylim@sejong.ac.kr \\ Received July 25, 2011, Accepted August 10, 2011
}

Key Words : Pentaaza macrocycle, ROS, SOD mimic, Manganese complex

Reactive oxygen species (ROS) are generated from cellular metabolism or from other environmental stresses in living organisms, and they are well known to oxidize cellular components including proteins, nucleic acids, and lipids, causing various types of cell and tissue damage. Therefore, antioxidant compounds have been considered as therapeutic agents to treat a variety of ROS-related disorders, including arthritis, ${ }^{1}$ stroke, ${ }^{2,3}$ Parkinson's disease, ${ }^{4}$ ALS (Lou Gehrig's disease), ${ }^{5}$ cancer, ${ }^{6}$ and aging. ${ }^{7-9}$ Intensive efforts have been made to find natural or synthetic chemicals that can remove ROS efficiently. One approach involved the development of a catalytic system that mimics natural antioxidant enzymes such as superoxide dismutases (SODs) or catalases. Thus far, many small molecules possessing catalytic antioxidant activity have been developed ${ }^{10}$ and tested in vivo. ${ }^{11-13}$ Such catalytic antioxidants include metal complexes of nitrogen- or phenol-based ligands such as $\mathrm{Mn}(\mathrm{III})$ and $\mathrm{Fe}(\mathrm{III})$ porphyrin complexes, ${ }^{14,15} \mathrm{Mn}$ (II) complexes of pentaaza macrocycles, ${ }^{16,17} \mathrm{Mn}$ (II) complexes centered on tripodal ligands, ${ }^{18-20} \mathrm{Mn}$ (III) salen complexes, ${ }^{13,21}$ and the tetra-aza[14]annulene-Fe(III) complex. ${ }^{22}$ These metal complexes closely mimic the active site of natural antioxidant enzymes, and the redox property of the metal ion in the complex is critical to their activity. Among these systems, the $\mathrm{Mn}(\mathrm{II})$ complexes of pentaaza macrocyclic ligands seem to be the most thoroughly investigated molecules for an in vivo disease model. ${ }^{16}$ A variety of $\mathrm{Mn}(\mathrm{II})$ complexes of C-substituted 1,4,7,10,13-pentaaza cyclopentadecane $\left([15] \mathrm{aneN}_{5}\right)$ have been prepared, ${ }^{23,24}$ and, in particular, a methyl and fuzed cycloalkyl substituent on the carbon or pyridino derivative of the core structure, [15] aneN $_{5}$, exhibited high SOD-like activity. One of the optimized complexes, M40403 (Figure 1), showed antitumor, ${ }^{25}$ antiarthritis, ${ }^{16}$ and pain-relieving ${ }^{26}$ in vivo activities, and it received the orphan drug designation in the US and Europe for the prevention of radiation- or chemotherapyinduced oral mucositis in cancer patients.

The molecular mechanism of Mn(II)-pentaaza macrocyclic complexes is still not entirely understood; however different rate determining steps for superoxide dismutation have been proposed based on stopped flow or pulsed radiolysis experiments. ${ }^{27,28}$ Investigations of the catalytic mechanism have indicated that the conformational and coordinational changes in Mn-pentaaza macrocyclic complexes and their reactivity with the second approaching $\mathrm{O}_{2}{ }^{--}$ could be an important factor for the good activity. As the catalytic activity of SOD enzymes is still unmatched by the existing SOD mimetics at a physiological $\mathrm{pH}$, there is scope for improvement to be made, possibly by changing the charge distribution in the ligand and substituent groups to increase its affinity for $\mathrm{O}_{2}{ }^{--}$. In this regard, a ligand modification strategy is still viable, and specifically, the incorporation of a positive charge near the manganese ion could favor the access of $\mathrm{O}_{2}{ }^{\cdot-}$.

Previously, we reported the synthesis and SOD-like activities of the $\mathrm{Mn}$ (II) complexes of pentaaza macrocyclic ligands, in which various functional groups can be placed in the axial position of the manganese complex (Figure 1). ${ }^{29}$ In this paper, we describe an efficient synthesis and manganese complexes of new pentaaza macrocycles having an aminoor guanidino-alkyloxyphenyl substituent on the pyridine ring. Their SOD-like activity was determined via a cytochrome c assay and compared with that of the standard compound, M40403.

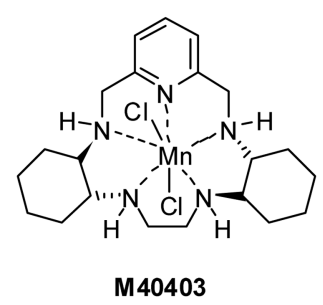

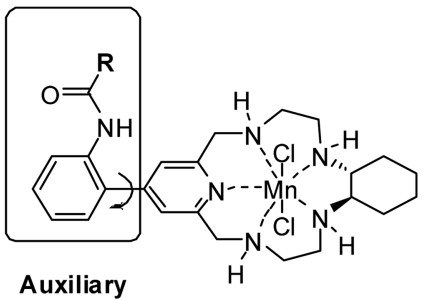

Previous work

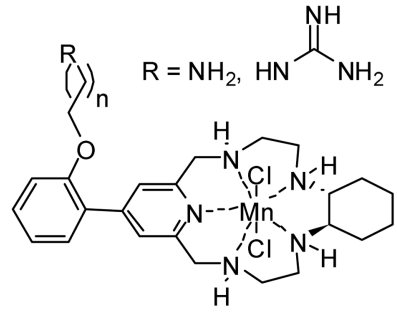

This work

Figure 1. Structure of Mn(II) complexes of pentaaza macrocycles. 


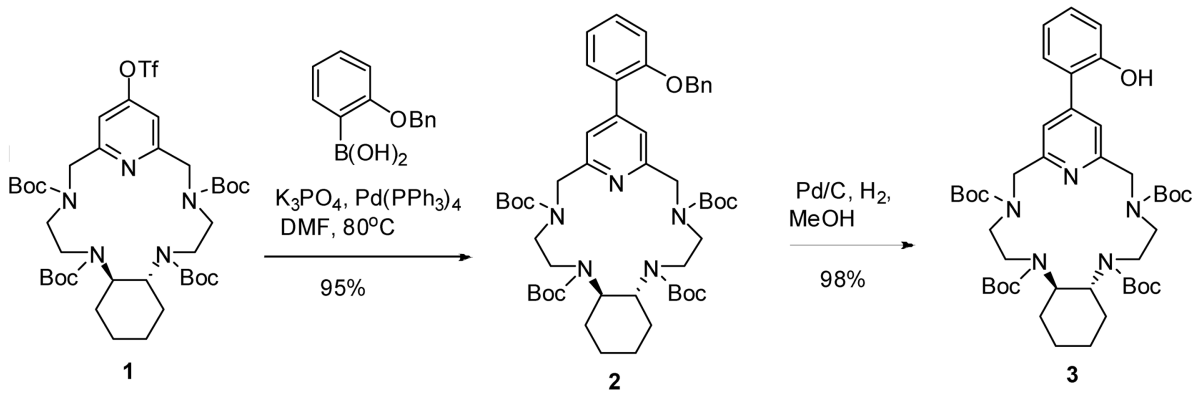

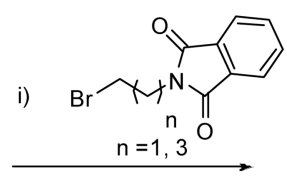

ii) $\mathrm{H}_{2} \mathrm{NNH}_{2}, \mathrm{MeOH}$

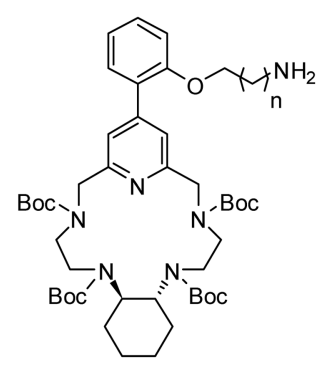

4a: $n=1,78 \%$

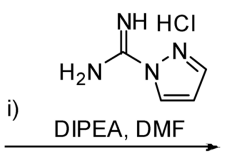

ii) $\mathrm{HCl}$, acetone

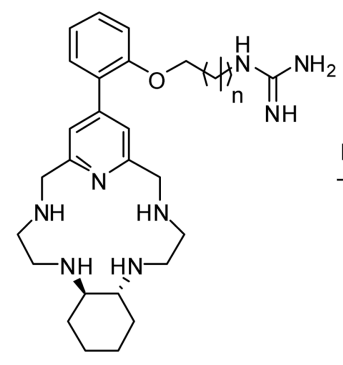

$\mathbf{5 a}: \mathrm{n}=1,86 \%$
$\mathbf{5 b}: \mathrm{n}=3,90 \%$

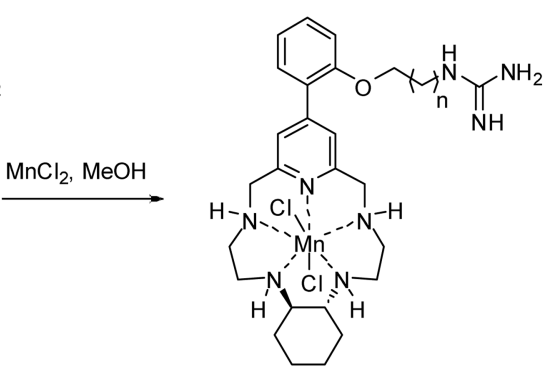

6a: $n=1,89 \%$

Scheme 1. Synthesis of manganese complexes of pentaaza macrocycle.

Synthesis of the guanidino analogs of the manganese complex, 6a and $\mathbf{6 b}$, was carried out as in Scheme 1. The triflate 1 was prepared in six steps from trans-cyclohexyldiamine $^{29}$ and coupled to 2-benzyloxyphenylboronic acid via the Suzuki reaction ${ }^{30,31}$ to provide the biaryl analog 2 in a $95 \%$ yield. The benzyl group was then removed to provide the phenol analog 3 under the $\mathrm{Pd} / \mathrm{C}$ hydrogenolysis condition. The aminoethyl and aminobutyl analogs of the phenol $\mathbf{3}$ were prepared by coupling with bromoalkyl phthalimides and the subsequent removal of the amino protecting group. The amino group in $\mathbf{4 a}$ and $\mathbf{4 b}$ was then converted to guanidine with pyrazole-1-carboxamidine. ${ }^{32}$ The four Boc protecting groups of the guanidinylated intermediate were removed under a $\mathrm{HCl} /$ acetone condition to furnish two ligands, $\mathbf{5} \mathbf{a}$ and $\mathbf{5 b}$, with $85-97 \%$ yields. The products were then complexed with $\mathrm{MnCl}_{2}$ in $\mathrm{MeOH}$ to afford new SOD enzyme mimetics, $\mathbf{6 a}$ and $\mathbf{6 b}$, containing a guanidinyl auxiliary that could be positioned over the plane of the Mn complex.

A new SOD mimic with an aminoethyl auxiliary 7 was also prepared from 4a via a similar procedure, as shown in Scheme 2, in order to verify the effect of aminoethyl sub-
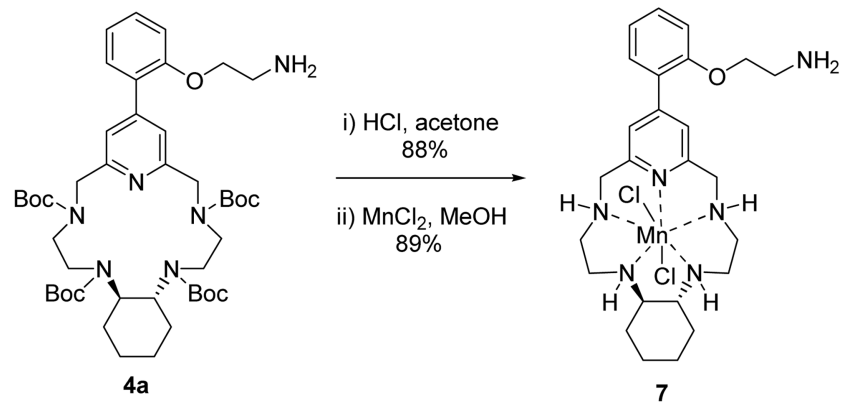

Scheme 2. Boc deprotection and metal complexation of $\mathbf{4 a}$.
Table 1. SOD-like activities of new compounds

\begin{tabular}{cc}
\hline Compound & $\begin{array}{c}\text { SOD activity }^{a} \\
\mathrm{IC}_{50}, \mu \mathrm{M}\end{array}$ \\
\hline $\mathbf{M - 4 0 4 0 3}$ & $2.7(0.6)$ \\
$\mathbf{6 a}$ & $0.71(0.28)$ \\
$\mathbf{6 b}$ & $0.52(0.05)$ \\
$\mathbf{7}$ & $0.39(0.06)$ \\
\hline
\end{tabular}

${ }^{\mathrm{a}}$ Values are averages of duplicate determinations at $\mathrm{pH}=7.8$; standard deviation is given in parentheses.

stitution on its activity.

The new manganese complexes prepared in this study were tested for their SOD-like activity, and the results are listed in Table 1.

The SOD-like activity of the new complexes was measured by an indirect method using cytochrome $\mathrm{c}$ as an electron acceptor as described by McCord and Freidovich. ${ }^{33}$

Among the compounds tested in this study, the amino analog 7 exhibited the best SOD-like activity, possessing about a 7-fold lower $\mathrm{IC}_{50}$ than the standard compound, $\mathrm{M}$ 40403. The guanidinyl analogs, $\mathbf{6 a}$ and $\mathbf{6 b}$, also showed activities that were significantly better than that of the standard compound, but were lower than that of 7. From the conformational analysis of the ligand, we expected that the amino- or guanidinyl-group on the ortho position of the phenyl auxiliary could be positioned over the plane of the Mn complex via the rotation of the biaryl linkage, and that the catalytic cycle of superoxide dismutation would be influenced by the functional group.

In summary, we have prepared new manganese complexes of pentaaza macrocyclic ligands bearing an amino- or guanidinyl-group in the vicinity of the metal site and compared their activities. The SOD-like activities of these new com- 
plexes were significantly more potent than that of the standard compound, M40403. Further study is needed to understand the effects of the amino- or guanidinyl- group on the catalytic cycle of superoxide dismutation.

Acknowledgments. This research was supported by a grant from the Marine Biotechnology Program, funded by the Ministry of Land, Transport and Maritime Affairs, Republic of Korea.

\section{References}

1. Afonso, V.; Champy, R.; Mitrovic, D.; Collin, P.; Lomri, A. Joint Bone Spine 2007, 74, 324-329.

2. Slemmer, J. E.; Shacka, J. J.; Sweeney, M. I.; Weber, J. T. Curr. Med. Chem. 2008, 15, 404-414.

3. Ginsberg, M. D. Neuropharmacology 2008, 55, 363-389.

4. Liang, L.-P.; Huang, J.; Fulton, R.; Day, B. J.; Patel, M. J. Neurosci. 2007, 27, 4326-4333.

5. Jung, C.; Rong, Y.; Doctrow, S.; Baudry, M.; Malfroy, B.; Xu, Z. Neurosci. Lett. 2001, 304, 157-160.

6. Lau, A. T.; Wang, Y.; Chiu, J. F. J. Cell Biochem. 2008, 104, 657667.

7. Melov, S.; Ravenscroft, J.; Malik, S.; Gill, M. S.; Walker, D. W.; Clayton, P. E.; Wallace, D. C.; Malfroy, B.; Doctrow, S. R.; Lithgow, G. J. Science 2000, 289, 1567-1569.

8. Melov, S.; Doctrow, S. R.; Schneider, J. A.; Haberson, J.; Patel, M.; Coskun, P. E.; Huffman, K.; Wallace, D. C.; Malfroy, B. J. Neurosci. 2001, 21, 8348-8353.

9. Taub, J.; Lau, J. F.; Ma, C.; Hahn, J. H.; Hoque, R.; Rothblatt, J.; Chalfie, M. Nature 1999, 399, 162-166.

10. Wu, A. J.; Penner-Hahn, J. E.; Pecoraro, V. L. Chem. Rev. 2004, 104, 903-938.

11. Riley, D. P. Chem. Rev. 1999, 99, 2573-2588.

12. Day, B. J. Drug Discov. Today 2004, 9, 557-566.

13. Munroe, W.; Kingsley, C.; Durazo, A.; Gralla, E. B.; Imlay, J. A.; Srinivasan, C.; Valentine, J. S. J. Inorg. Biochem. 2007, 101, 1875-1882.

14. Lahaye, D.; Muthukumaran, K.; Hung, C.-H.; Gryko, D.; Reboucas, J. S.; Spasojevic, I.; Batinic-Haberle, I.; Lindsey, J. S. Bioorg.
Med. Chem. 2007, 15, 7066-7086.

15. Patel, M.; Day, B. J. Trends Pharmacol. Sci. 1999, 20, 359-364.

16. Salvemini, D.; Riley, D. P.; Cuzzocrea, S. Nat. Rev. Drug Discov 2002, 1,367-374.

17. Cuzzocrea, S.; Mazzon, E.; Paola, R. D.; Genovese, T.; Muià, C.; Caputi, A. P.; Salvemini, D. Arthritis Rheum. 2005, 52, 19291940.

18. Durot, S.; Lambert, F.; Renault, J.-P.; Policar, C. Eur. J. Inorg. Chem. 2005, 14, 2789-2793.

19. Lewis, E. A.; Khodr, H. H.; Hider, R. C.; Lindsay-Smith, J. R.; Walton, P. H. J. Chem. Soc., Dalton trans. 2004, 2, 187-188.

20. Lewis, E. A.; Lindsay-Smith, J. R.; Walton, P. H.; Archibald, S. J.; Foxon, S. P.; Giblin, G. M. P. J. Chem. Soc., Dalton trans. 2001, $1159-1161$.

21. Doctrow, S. R.; Huffman, K.; Marcus, C. B.; Tocco, G.; Malfroy, E.; Adinolfi, C. A.; Kruk, H.; Baker, K.; Lazarowych, N.; Mascarenhas, J.; Malfroy, B. J. Med. Chem. 2002, 45, 4549-4558.

22. Paschke, J.; Kirsch, M.; Korth, H.-G.; de Groot, H.; Sustmann, R. J. Am. Chem. Soc. 2001, 123, 11099-11100.

23. Weiss, R. H.; Fretland, D. J.; Baron, D. A.; Ryan, U. S.; Riley, D. P. J. Biol. Chem. 1996, 271, 26149-26156.

24. Salvemini, D.; Wang, Z. Q.; Zweier, J. L.; Samouilov, A.; Macarthur, H.; Misko, T. P.; Currie, M. G.; Cuzzocrea, S.; Sikorski, J. A.; Riley, D. P. Science 1999, 286, 304-306.

25. Samlowski, W. E.; Petersen, R.; Cuzzocrea, S.; Macarthur, H.; Burton, D.; McGregor, J. R.; Salvemini, D. Nat. Med. 2003, 9, 750-755.

26. De Bono, S. Trends Biochem. Sci. 2001, 26, 283.

27. Maroz, A.; Kelso, G. F.; Smith, R. A. J.; Ware, D. C.; Anderson, R. F. J. Phys. Chem. A 2008, 112, 4929-4935.

28. Dees, A.; Zahl, A.; Puchta, R.; van Eikema Hommes, N. J. R.; Heinemann, F. W.; Ivanovic-Burmazovic, I. Inorg. Chem. 2007, 46, 2459-2470.

29. Lee, H.; Park, W.; Lim, D. Bioorg. Med. Chem. Lett. 2010, 20 , 2421-2424.

30. Oh-e, T.; Miyaura, N.; Suzuki, A. Synlett 1990, 221-223.

31. Oh-e, T.; Miyaura, N.; Suzuki, A. J. Org. Chem. 1993, 58, 22012208.

32. Bernatowicz, M. S.; Wu, Y.; Matsueda, G. R. J. Org. Chem. 2002, 57, 2497-2502

33. McCord, J. M.; Fridovich, I. J. Biol. Chem. 1969, 244, 6049-6055. 